\title{
Comparative Studies of Nitrogen Fixation by Soybean Root Nodules, Bacteroid Suspensions and Cell-free Extracts
}

\author{
By F. J. BERGERSEN AND G. L. TURNER \\ Division of Plant Industry, CSIRO, Canberra, Australia
}

(Accepted for publication 3 April 1968)

SUMMARY

Rhizobium japonicum (CC7I I) was used to infect soybean seeds from which plants were grown. From the root nodules, bacteroid suspensions with initial rates of nitrogen fixation as high as those calculated for bacteroids in intact nodules were prepared. Oxygen, which was required for fixation by intact nodules and bacteroid suspensions, caused the eventual loss of bacteroid nitrogen-fixing ability, accompanied by an increase in $\mathrm{O}_{2}$-uptake. In intact nodules and in bacteroid suspensions, increasing $\mathrm{O}_{2}$ pressures resulted in higher values for $K_{m}$ of nitrogen fixation. $V_{\max }$ also increased with increasing $p \mathrm{O}_{2}$ and this was shown to be consistent with the characteristics of nitrogen fixation by anaerobic cell-free extracts of bacteroids which required an energy source (ATP), and a reductant (sodium dithionite).

Higher concentrations of carbon monoxide were required to inhibit nitrogen fixation by intact nodules than by bacteroid suspensions. Carbon monoxide was a competitive inhibitor of nitrogen fixation in bacteroid suspensions and $K_{i}(\mathrm{CO})$ and $K_{m}\left(\mathrm{~N}_{2}\right)$ values showed that the nitrogenase had about 30 times the apparent affinity for $\mathrm{CO}$ that it had for $\mathrm{N}_{2}$.

In cell-free extracts of bacteroids, the nitrogen-fixing activity remained in the supernatant fluid after centrifugation at $100,000 \mathrm{~g}$ for $30 \mathrm{~min}$. The extracts were inactivated at $0^{\circ}$. The $K_{m}$ for nitrogen fixation by cell-free extracts was variable, $62-\mathrm{II} 8\left(\mathrm{~N}_{2}\right.$ concentration in $\mathrm{mm}$. $\mathrm{Hg}$. pressure), compared with 50-60 for intact nodules and 20 for intact bacteroids when $K_{m}$ for these was measured in the range of $p \mathrm{O}_{2}$ in which it was only slightly affected by $\mathrm{O}_{2}$. The $K_{i}$ for inhibition of nitrogen fixation by $\mathrm{CO}$ in extracts was similar to values obtained with intact bacteroids.

\section{INTRODUCTION}

Considerable understanding of the biochemistry of nitrogen fixation has developed since 1960 as a result of studies with cell-free extracts of free-living nitrogen-fixing bacteria (e.g. Azotobacter vinelandii, Bulen, Burns \& LeComte, I965; Clostridium pasteurianum, Mortenson, I966). The symbiotic nitrogen-fixing system of legume nodules has been studied in intact detached nodules since the work of Aprison, Magee \& Burris (1954), in nodule breis (Bergersen, 1966) and has been shown to be located wholly in the bacteroids (Bergersen \& Turner, 1967). Koch, Evans \& Russell $(1967 a, b)$ showed that the properties of cell-free extracts of Rhizobium bacteroids in many respects resemble those of extracts prepared from Azotobacter or Clostridium. The results to be given in the present paper are in substantial agreement with their results. In nature, it is the intact nodule tissue which accomplishes nitrogen fixation 
and it is important to relate these new findings to the active component of the intact system, the bacteroids, which have developed the ability to perform this function only after growth within the complex structures of the nodule cells.

The effects of $\mathrm{O}_{2}$ upon nitrogen fixation in detached intact nodules were studied by Bergersen (1962) but the inhibition of nitrogen fixation in this system by $\mathrm{CO}$ has only been studied in experiments with whole growing plants (Lind \& Wilson, I94I). In the present paper, an account is given of experiments in which the effects of $\mathrm{O}_{2}$ and $\mathrm{CO}$ upon intact nodules and Rhizobium bacteroid suspensions are compared and some properties of cell-free extracts of bacteroids are related to these effects.

\section{METHODS}

Nodules. Soybean plants (cv. Shelby) were grown in sand + vermiculite mixture in a glasshouse, as previously described (Bergersen, I958), from seeds inoculated at sowing with strain CC7II of Rhizobium japonicum. Nodules were detached when they were aged about 35 days, and were used immediately.

Bacteroid suspensions. Breis were prepared under argon using a stainless-steel anaerobic press and washed bacteroids were prepared from the breis as previously described (Bergersen, 1966; Bergersen \& Turner, 1967). In some experiments the suspending and washing medium contained $0.3 \mathrm{M}$-sucrose, $0 . \mathrm{I} \mathrm{M}-\mathrm{KH}_{2} \mathrm{PO}_{4}(\mathrm{pH} 7.0)$ and I mM$\mathrm{MgSO}_{4}$. Following the work of Koch et al. (1967a), in which polyvinyl-pyrrolidone and ascorbate were used to remove plant polyphenols, the method was modified and the initial brei was prepared in $0 . \mathrm{I} \mathrm{M}-\mathrm{KH}_{2} \mathrm{PO}_{4}(\mathrm{pH} 7 \cdot 0)$ containing $\mathrm{I} \cdot 5 \%(\mathrm{w} / \mathrm{v})$ of a soluble polyvinyl-pyrrolidone (PVP) of average molecular weight 25,000 (Kollidon 25; B.A.S.F., Australia Ltd.) and $0.2 \mathrm{M}-\mathrm{Na}$ ascorbate. The bacteroids were then centrifuged down, and washed in buffered sucrose medium with the phosphate concentration decreased to $0.025 \mathrm{M}$. This modification followed the observation of inhibition of nitrogen fixation at higher phosphate concentrations (Bergersen, unpublished). The bacteroids prepared by the modified method were more active but their properties were otherwise unaltered.

Gas mixtures. These were prepared from good quality commercial gases and the composition is expressed as partial pressures measured in $\mathrm{mm} . \mathrm{Hg}$. ${ }^{15} \mathrm{~N}_{2}$ was included in the gas mixtures or added to incubation vessels by syringe. Mixtures for anaerobic experiments were stored over a solution of chromous sulphate to remove traces of $\mathrm{O}_{2}$. Mass spectrometer analysis was used to check gas composition in the vessels before and after incubation and also to measure respiration and evolution of $\mathrm{H}_{2}$. In experiments with $\mathrm{CO}$ this inhibitor was injected into the reaction vessels by means of a gas chromatograph syringe.

Measurements of nitrogen fixation. Intact nodules ( $\mathrm{I} \cdot 5 \mathrm{~g}$. fresh wt) were incubated in $50 \mathrm{ml}$. Erlenmeyer flasks containing the desired gas mixture, the nodules then ground in $3 \mathrm{~N}-\mathrm{HCl}$ and the soluble portion containing the non-protein nitrogen analysed for ${ }^{15} \mathrm{~N}$.

Washed bacteroid suspensions evolve $\mathrm{NH}_{3}-\mathrm{N}$ from endogenous sources into the medium in addition to the accumulation of fixed $\mathrm{NH}_{3}-\mathrm{N}$. This is illustrated by the data from an experiment in which $3.75 \mu \mathrm{g}$. $\mathrm{NH}_{3}-\mathrm{N}$ accumulated in the medium, while only $0.49 \mu \mathrm{g}$. was fixed. These effects, while of much smaller magnitude than reported for unfractionated nodule breis (Bergersen, 1966), are still sufficient to prevent the 
use of direct nitrogen analysis for the measurement of nitrogen fixation; ${ }^{15} \mathrm{~N}$ methods must therefore continue to be used. Fixation by bacteroid suspensions and by cell-free extracts was measured by using sidearm flasks with a gas volume of 30 or $70 \mathrm{ml}$. and containing 3 to $6 \mathrm{ml}$. liquid. The flasks were shaken at $25^{\circ}$ and substrates, when used, were tipped from a sidearm. The fixed nitrogen accumulated as $\mathrm{NH}_{3}-\mathrm{N}$ in the suspending medium (Bergersen \& Turner, 1967). The ${ }^{15} \mathrm{~N}$ content of this nitrogen was measured in the following manner in I ml. samples of suspension, withdrawn at intervals by hypodermic syringe from rubber-capped sidearms. The samples were centrifuged at 0 to $4^{\circ}$ and the bacteroid pellet washed once with a further portion of the suspending medium. The combined supernatant fluids, with 50 or $100 \mu \mathrm{g}$. unlabelled $\mathrm{NH}_{3}-\mathrm{N}$ as carrier, were distilled from a Markham still after adding an equal volume of saturated borate buffer $(\mathrm{pH} \mathrm{IO} \cdot 5)$ and the distilled $\mathrm{NH}_{3}$ trapped in $5 \mathrm{ml}$. I \% (w/v) boric acid. Alternatively, the $\mathrm{NH}_{3}$ in the samples was recovered by diffusion from a suspension with $\mathrm{MgO}$ in modified Conway dishes (Freney \& Wetselaar, 1967). After titration of the $\mathrm{NH}_{3}-\mathrm{N}$, it was analysed for ${ }^{15} \mathrm{~N}$ content and the $\mu \mathrm{g}$. $\mathrm{N}$ fixed/vessel was calculated with regard to the initial liquid volume, the $\mathrm{NH}_{3}-\mathrm{N}$ content of the samples (including the carrier $\mathrm{NH}_{3}-\mathrm{N}$ ), the atoms $\%{ }^{15} \mathrm{~N}$ excess of the $\mathrm{N}_{2}$ in the gas mixture and the atoms $\%{ }^{15} \mathrm{~N}$ excess of the samples.

Protein determination. Because of the use of intact bacteroids it was necessary to use a protein- $\mathrm{N}$ method which was used throughout for whole nodules, bacteroids and extracts. Samples $(0.5 \mathrm{ml}$.) of suspension or extract or a sample of ground dried nodules, were extracted with $4 \mathrm{ml}$. $0 . \mathrm{I} \mathrm{N}-\mathrm{H}_{2} \mathrm{SO}_{4}$ containing $0.5 \mathrm{ml}$. Na tungstate (IO $\%$, w/v). The precipitate, after overnight extraction and washing, was digested and the protein- $\mathrm{N}$ determined after distillation and titration. Protein $(\mathrm{mg}$.) was given by $6.37 \times \mathrm{mg}$. protein-N.

Bacteroid extracts. The bacteroids after washing were suspended in $15 \mathrm{ml} .0 .025 \mathrm{M}-$ $\mathrm{KH}_{2} \mathrm{PO}_{4}$ ( $\mathrm{pH} 7 \cdot 4$ ) containing $2 \mathrm{mM}-\mathrm{MgSO}_{4}$, under argon, and transferred to a previously argon-flushed pressure-release cell designed in the Division of Plant Industry, CSIRO, Canberra. Deoxyribonuclease (about I $\mu$ g.; Mann Research Laboratories, New York) was added and the piston inserted under a stream of argon. The bacteroids were broken by using a pressure of 8 tons/sq. in. and the extract collected and centrifuged under argon. Extracts (total volume 3 to $5 \mathrm{ml}$.) were shaken with ${ }^{15} \mathrm{~N}_{2}+$ argon mixtures at $25^{\circ}$ with various additions. The ATP-generating system consisted of $6 \mu$ moles adenosine-5-triphosphate ( $\mathrm{Na}$ salt; Nutritional Biochemicals $\mathrm{Co}$., Cleveland, Ohio), $150 \mu$ moles creatine phosphate and $\mathrm{I}-2 \mathrm{mg}$. creatine phosphokinase (Sigma Chemical Co., St Louis, Mo.) all dissolved in $0.025 \mathrm{M}-\mathrm{KH}_{2} \mathrm{PO}_{4}$ and neutralized. The dithionite $\left(\mathrm{Na}_{2} \mathrm{~S}_{2} \mathrm{O}_{4} \cdot 2 \mathrm{H}_{2} \mathrm{O}, 24 \mu\right.$ moles/vessel), made up daily, was dissolved in argonsaturated phosphate buffer $\left(\mathrm{O}^{\circ} \mathrm{I} \mathrm{M} ; \mathrm{pH} 7{ }^{\circ}\right.$ ) and stored under argon at $\mathrm{O}^{\circ}$ until used. The incubation vessels with the constituents of the ATP-generating system in the sidearms, were flushed three times with argon and then filled with gas mixture to a predetermined pressure and the extracts added by syringe through a rubber-capped port in one sidearm. The dithionite was added last, also by syringe. $\mathrm{NH}_{3}$ was recovered from the flask contents by distillation from saturated borate $(\mathrm{pH}$ 10.5), titrated and analyzed for ${ }^{15} \mathrm{~N}$, and the amount of nitrogen fixed calculated as described above. 


\section{RESULTS}

\section{Comparison of bacteroid and nodule activity}

Nitrogen fixation was greatest in bacteroid suspensions prepared from nodules disrupted in the presence of buffered PVP and ascorbate and washed and incubated in buffered sucrose containing I mM- $\mathrm{Mg}^{2+}$ and $16.7 \mathrm{~mm}-\mathrm{Na}$ succinate. Initial fixation rates (o to $20 \mathrm{~min}$.) of 700 to $900 \mathrm{~m} \mu \mathrm{g}$. $\mathrm{N} / \mathrm{mg}$. protein $/ \mathrm{hr}$ with $\mathrm{pO}_{2} 42 \mathrm{~mm}$. Hg and $p \mathrm{~N}_{2}$ I $40 \mathrm{~mm}$. $\mathrm{Hg}$ at $25^{\circ}$, was consistently obtained with this method. Bacteroids prepared from nodules disrupted in buffered sucrose (Bergersen \& Turner, I967) had initial fixation rates of $450-500 \mathrm{~m} \mu \mathrm{g}$. $\mathrm{N} / \mathrm{mg}$. protein $/ \mathrm{hr}$ under the same conditions. To compare these rates of nitrogen fixation with the rates of fixation by bacteroids in intact nodule tissue, samples of nodules aged 35 days were incubated for $\mathrm{I} \mathrm{hr}$ at $25^{\circ}$ and the nitrogen-fixation rates and protein content of the nodules measured. These nodules contained $179 \mathrm{mg}$. protein and they fixed at a rate of $2 \mathrm{I} \mu \mathrm{g} . \mathrm{N} / \mathrm{hr}$ at $p \mathrm{O}_{2}$ I40 mm. $\mathrm{Hg}$, and at a rate of $60 \mu \mathrm{g}$. $\mathrm{N} / \mathrm{hr}$ at $p \mathrm{O}_{2} 350 \mathrm{~mm}$. $\mathrm{Hg}$ (both with $p \mathrm{~N}_{2}$ I $40 \mathrm{~mm}$. $\mathrm{Hg}$ ). In previous work (Bergersen \& Turner, 1967, Table II), bacteroid protein accounted for about $56 \%$ of the nodule brei protein. Assuming the same proportion, the above rates of nitrogen fixation by intact nodules can be expressed as 210 and $599 \mathrm{~m} \mu \mathrm{g}$. $\mathrm{N} / \mathrm{mg}$. bacteroid protein $/ \mathrm{hr}$ at $\mathrm{pO}_{2}$ values of $\mathrm{I} 40$ and $350 \mathrm{~mm}$. $\mathrm{Hg}$, respectively. From these results it is concluded that bacteroids prepared anaerobically in the manner described are comparable in their initial nitrogen-fixing capacity with bacteroids in intact nodule tissue, although the high rates of fixation by suspensions are transitory (Fig. I).

\section{Effects of $\mathrm{O}_{2}$ upon bacteroid suspensions}

The results obtained were similar to those obtained with nodule breis (Bergersen, 1966); air had to be excluded during preparation of the bacteroids, but $\mathrm{O}_{2}$ was required for nitrogen fixation. Table I shows the effect of vigorously aerating a bacteroid

Table I. Inactivation of bacteroids by aeration

Inactivation was by bubbling air for $15 \mathrm{~min}$. at $0^{\circ}$. Aerated treatments contained $53 \mathrm{mg}$. bacteroid protein/vessel and non-aerated treatments $48 \mathrm{mg}$. bacteroid protein/vessel. Incubated $30 \mathrm{~min}$. at $23^{\circ}$ with ${ }^{15} \mathrm{~N}_{2}(\mathrm{I} 68 \mathrm{~mm} . \mathrm{Hg})$ and $\mathrm{O}_{2}(42 \mathrm{~mm}$. $\mathrm{Hg})$. Respiration and $\mathrm{H}_{2}$ evolution measured mass-spectrometrically. Non-aerated bacteroids were also kept 15 min. at $0^{\circ}$. Bacteroids suspended in $0.1 \mathrm{M}$-phosphate $(\mathrm{pH} 7 \cdot 0)+1 \mathrm{mM}-\mathrm{Mg}^{2+}$.

\begin{tabular}{lccccc} 
& & & \multicolumn{2}{c}{ Respiration } \\
Treatment & $\begin{array}{c}\text { Succinate } \\
(\mathrm{I} 00 \mu \text { moles })\end{array}$ & $\begin{array}{c}\mathrm{N}_{2} \text { fixed } \\
\text { bacteroid } \\
\text { protein) }\end{array}$ & $\begin{array}{c}\mathrm{H}_{2} \text { evolution } \\
\left(\Delta p \mathrm{H}_{2} \text { atm. }\right)\end{array}$ & $\begin{array}{c}\Delta p \mathrm{O}_{2} \\
(\text { atm. }\end{array}$ & $\begin{array}{c}\Delta p \mathrm{CO}_{2} \\
(\mathrm{~atm})\end{array}$ \\
Aerated & - & 0 & 0 & $-46 \times 10^{-4}$ & $+48 \times 10^{-4}$ \\
Aerated & + & 43 & $1 \cdot 4 \times 10^{-4}$ & $-91 \times 10^{-4}$ & $+86 \times 10^{-4}$ \\
Non-aerated & - & 383 & $5 \cdot 5 \times 10^{-4}$ & $-90 \times 10^{-4}$ & $+53 \times 10^{-4}$ \\
Non-aerated & + & 424 & $6 \cdot 0 \times 10^{-4}$ & $-10 \mathrm{I} \times 10^{-4}$ & $+86 \times 10^{-4}$
\end{tabular}

suspension in sucrose-free medium for $15 \mathrm{~min}$. at $0^{\circ}$. First, this treatment decreased the endogenous $\mathrm{O}_{2}$ uptake, presumably because of depletion of endogenous substrate resulting from the vigorous agitation in the sucrose-free suspending medium. The $\mathrm{O}_{2}$ uptake was restored on adding succinate. These results may be compared with those obtained previously (Bergersen \& Turner, 1967) in which it was found that anaerobic 
washing of bacteroids in sucrose-free medium decreased the endogenous nitrogenfixing activity to a very low value, the activity being restored by adding succinate or other substrates. Secondly, nitrogen fixation and hydrogen evolution were reduced by the aeration, and these activities were not restored by adding succinate.

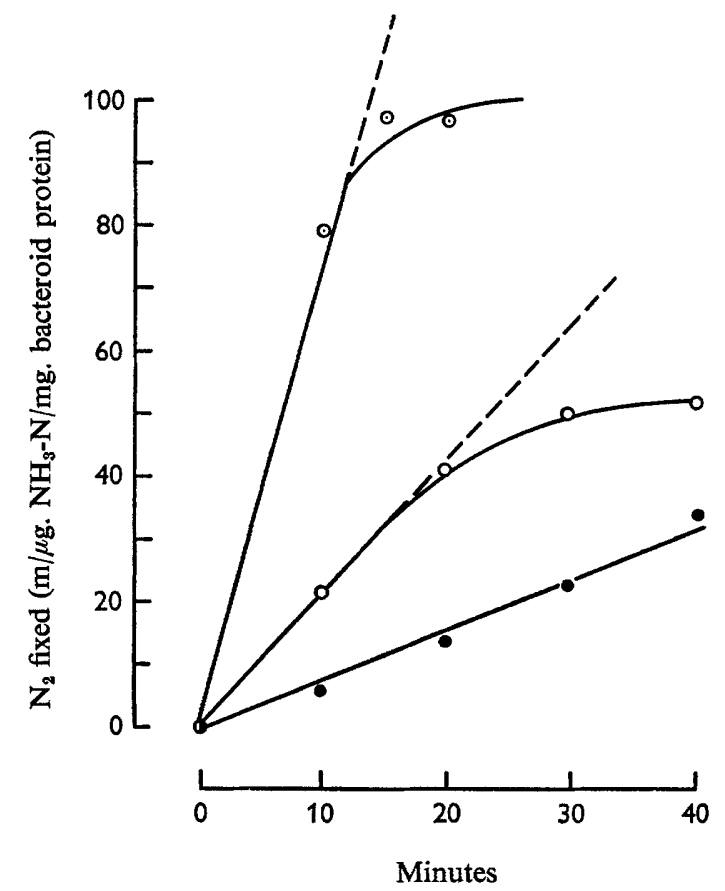

Fig. I. The effect of $\mathrm{O}_{2}$ concentration upon the time course of nitrogen fixation by washed bacteroids of Rhizobium japonicum. The dotted lines indicate the initial rates of fixation used for kinetic studies. The gas phase contained ${ }^{15} \mathrm{~N}_{2}(70 \mathrm{~mm} . \mathrm{Hg})$ and $p \mathrm{O}_{2}$ values $(\mathrm{mm} . \mathrm{Hg})$ of $-12 \mathrm{I}, \mathrm{O}-\mathrm{O} 42$ and $\odot \longrightarrow \odot 84$; the balance to $700 \mathrm{~mm}$. $\mathrm{Hg}$ was argon.
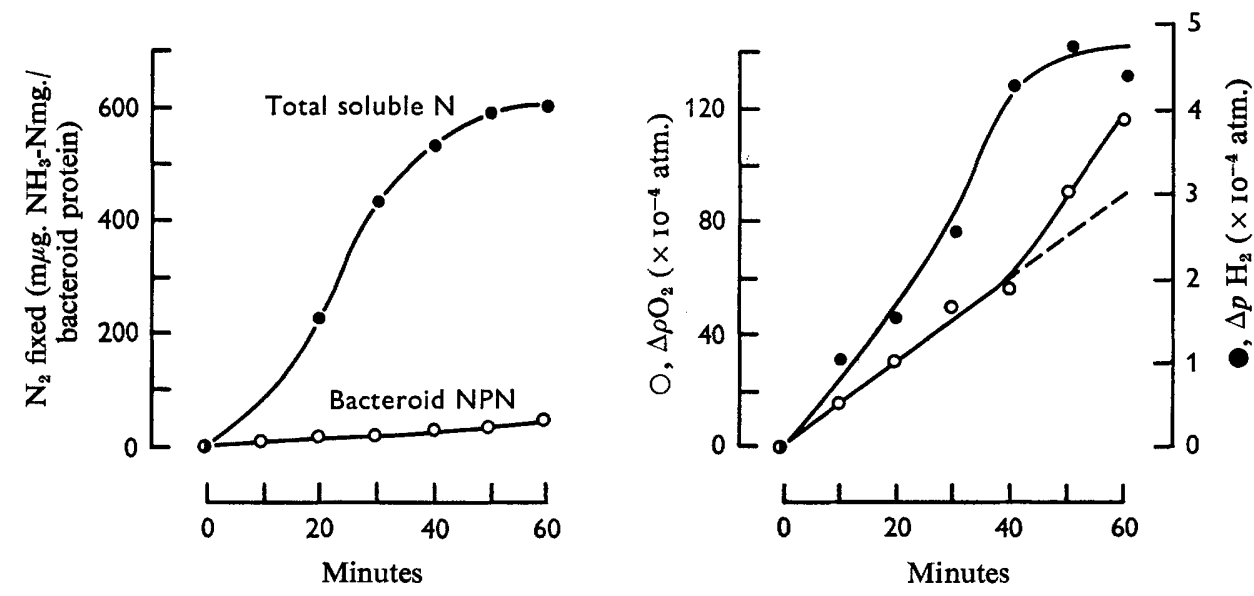

Fig. 2. The relationship between the time courses of nitrogen fixation, hydrogen evolution and respiration by washed bacteroids of $R$. japonicum. The distribution of the fixed $\mathrm{N}$ between non-protein-N (NPN) of bacteroids and suspending medium is also shown. 
In Fig. $\mathrm{I}$, the effect of $\mathrm{O}_{2}$ concentration upon the initial rates of nitrogen fixation and upon the time course are illustrated. Doubling the $\mathrm{pO}_{2}$ value more than doubled the initial fixation rates but the course was much shortened. The inactivation of the nitrogen-fixing activity of bacteroids during incubation in the presence of $\mathrm{O}_{2}$ may be due to the oxidation of labile-SH groups. Attempts to preserve the activity by the use of $\beta$-mercaptoethanol or thioglycollate (Fraenkel-Conrat, 1957) were unsuccessful; neither compound prolonged the activity and both were inhibitory to nitrogen fixation. The decline in fixation, which occurred after about $40 \mathrm{~min}$. with $p \mathrm{O}_{2} 42 \mathrm{~mm}$. $\mathrm{Hg}$ was accompanied by a decline in $\mathrm{H}_{2}$ evolution and by an increase in respiration rate. This is illustrated in the data of Fig. 2, which presents the results from an experiment in which 6 vessels were incubated for the times shown, before the gas phase was sampled and analysed and the distribution of the newly fixed $\mathrm{N}$ in the bacteroid suspension determined. During nitrogen fixation, only about $3-5 \%$ of the fixed $\mathrm{N}$ was found in the bacteroids after one washing, but after $60 \mathrm{~min}$. when fixation had ceased, this increased slightly to $7 \%$. In other experiments, the soluble $\mathrm{NH}_{3}-\mathrm{N}$, which accounted for most of the fixed $\mathrm{N}$ in this experiment, declined after fixation ceased. These observations suggested that there may have been some assimilation of newly fixed soluble $\mathrm{NH}_{3}-\mathrm{N}$ at this stage. This was been confirmed in experiments which showed slight labelling of $\alpha$-amino- $\mathrm{N}$ of the bacteroids after $40 \mathrm{~min}$.

\section{Effects of $\mathrm{O}_{2}$ upon reaction kinetic measurements with nodules and bacteroids}

The characteristics of an enzymic reaction are most conveniently described in terms of the Michaelis equation:

$$
v=V_{\max } s / K_{m}+s
$$

in which $v$ is the reaction velocity, $V_{\max }$ the velocity with non-limiting substrate concentrations, $s$ the substrate concentration and $K_{m}$ the equilibrium constant of the reversible combination of enzyme and substrate (the Michaelis constant). In the work to be described, $\mathrm{N}_{2}$ was the substrate and the values obtained were for the reduction of $\mathrm{N}_{2}$ to $\mathrm{NH}_{3}$.

In previous work with intact detached nodules (Bergersen, 1962) the apparent $K_{m}$ for nitrogen fixation increased sharply at high values of $\mathrm{OO}_{2}$ and was accompanied by inhibition of nitrogen fixation. Although $V_{m a x}$ also increased in this range of $p \mathrm{O}_{2}$ values, the increase was not significant and it was concluded that $\mathrm{O}_{2}$ was a competitive inhibitor of nitrogen fixation in this system.

The effects of $\mathrm{O}_{2}$ upon fixation by bacteroid suspensions appeared to be different: no inhibition was obtained at the highest concentration which permitted measurement of initial rates of nitrogen fixation. $K_{m}$ and $V_{m a x}$ for isolated bacteroids were therefore measured by using the reciprocal method of Dixon (1953). Six experiments were done, in each of which a pair of $p \mathrm{O}_{2}$ values was compared. The data are shown in Fig. 3. In this work $v$ was taken as the average rate of fixation over the first 10 or $20 \mathrm{~min}$. (see Fig. I) and $s$ was measured in portions of an atmosphere of $700 \mathrm{~mm}$. Hg. Statistical treatment was necessary in order to give confidence limits for the values obtained. A preliminary fit of $\mathrm{I} / v$ upon $\mathrm{I} / \mathrm{s}$ was made, ignoring the increasing array dispersion with $\mathrm{I} / s$. Deviates from the line were calculated and the absolute values of these plotted against estimated $\mathrm{I} / v$. A quadratic trend was indicated and it was found that the array standard deviation was proportional to $(\mathrm{I} / v)^{2}$. The values of $\mathrm{I} / v$ and $\mathrm{I} / \mathrm{s}$ 
were then fitted with weights inversely proportional to the fourth power of the estimated $\mathrm{I} / \mathrm{v}$ of the first fitting, and the confidence limits of the intercepts giving $\mathrm{I} / K_{m}$ and $\mathrm{I} / V_{\max }$ were calculated.
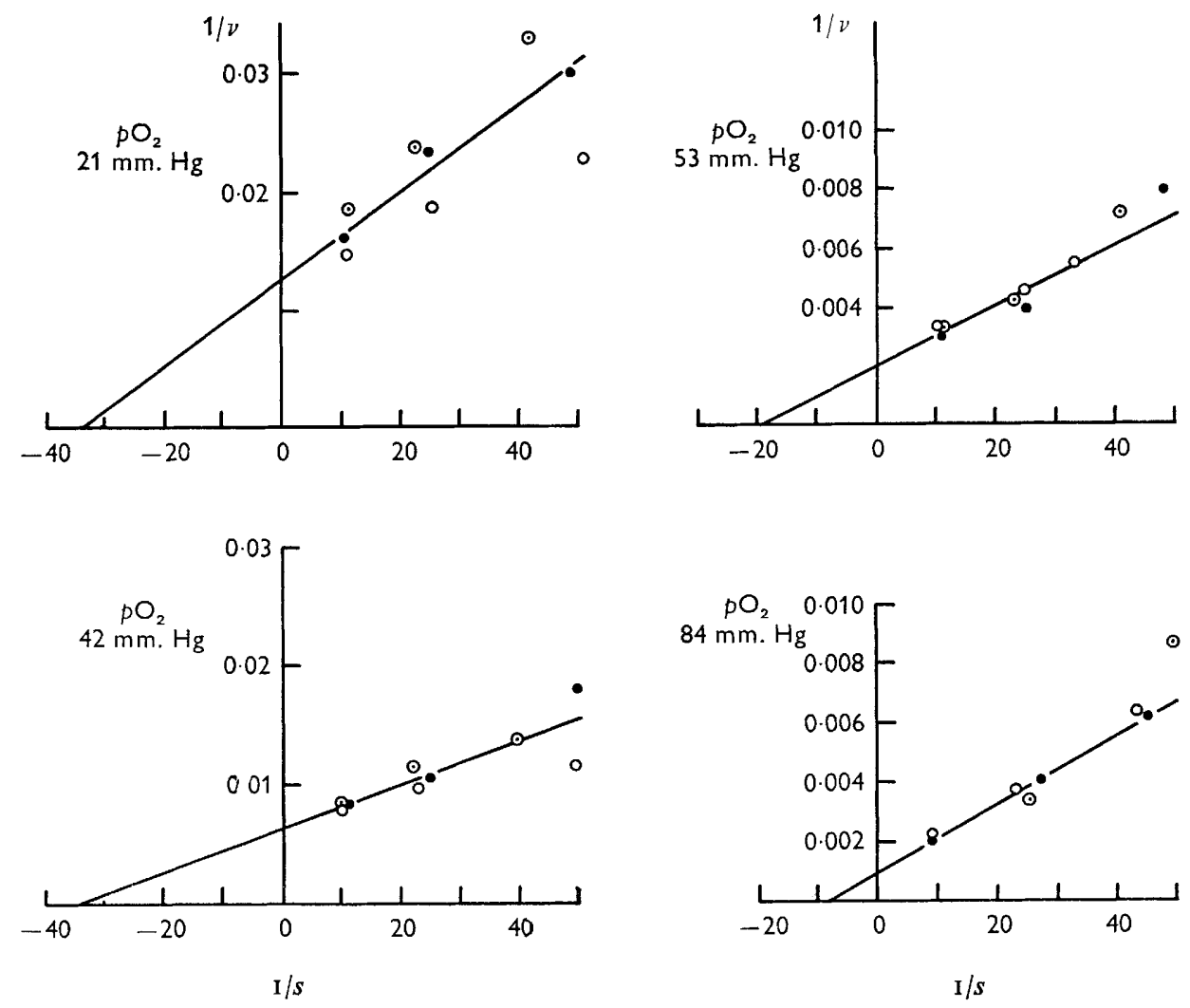

Fig. 3. Dixon-Lineweaver-Burk plots for nitrogen fixation by washed bacteroids of $R$. japonicum at $p \mathrm{O}_{2}$ values of $21,42,53$ and $84 \mathrm{~mm}$. $\mathrm{Hg} . v$ measured as initial fixation rates in $\mathrm{m} \mu \mathrm{g}$. N/mg. protein $/ \mathrm{hr}$ and $s$ as portions of an atmosphere of $700 \mathrm{~mm}$. $\mathrm{Hg}$. The regression lines are fitted according to the weighted method described in the text. In each case, data for 3 experiments are shown.

Both $K_{m}$ and $V_{\max }$ increased with increasing $p \mathrm{O}_{2}$ values over the range 52 to $84 \mathrm{~mm}$. $\mathrm{Hg}$, while from $2 \mathrm{I}$ to $42 \mathrm{~mm}$. $\mathrm{Hg}$ there was a significant increase in $V_{\max }$ but no change in $K_{m}$. In Fig. 4 these results are compared with data for intact nodules, used previously (Bergersen, 1962). Although no inhibition of nitrogen fixation by $\mathrm{O}_{2}$ was obtained with bacteroids, in both intact nodules and bacteroids the kinetic effects of $\mathrm{O}_{2}$ are comparable. A fourfold increase in $\mathrm{pO}_{2}$ changed $K_{m}$ and $V_{\max }$ by similar factors in each system, although with intact nodules the increase in $V_{\max }$ at high $p \mathrm{O}_{2}$ was not significant, because of large experimental error. It is clear that increasing $\mathrm{O}_{2}$ pressures decreased the apparent affinity of the nitrogenase for $\mathrm{N}_{2}$ as shown by the increased values of $K_{m}$ at higher $p \mathrm{O}_{2}$ values. At the same time, increasing $p \mathrm{O}_{2}$ values increased the velocity of the reaction. In these experiments it was observed that $\mathrm{O}_{2}$-uptake was greatest at the lowest $\mathrm{N}_{2}$ concentrations. This is in general agreement with results of 
experiments such as that illustrated in Fig. 2, which suggests competition between $\mathrm{O}_{2}$ and $\mathrm{N}_{2}$ for reducing power.

\section{The inhibition of nitrogen fixation by carbon monoxide}

The effect of carbon monoxide upon nitrogen fixation by intact nodules is shown in Fig. 5, which presents data from a series of experiments, in which samples of $1.5 \mathrm{~g}$. fresh weight of nodules were incubated for $\mathrm{I} \mathrm{hr}$ at $25^{\circ}$, with $p \mathrm{CO}$ values of o to $8 \mathrm{~mm}$.

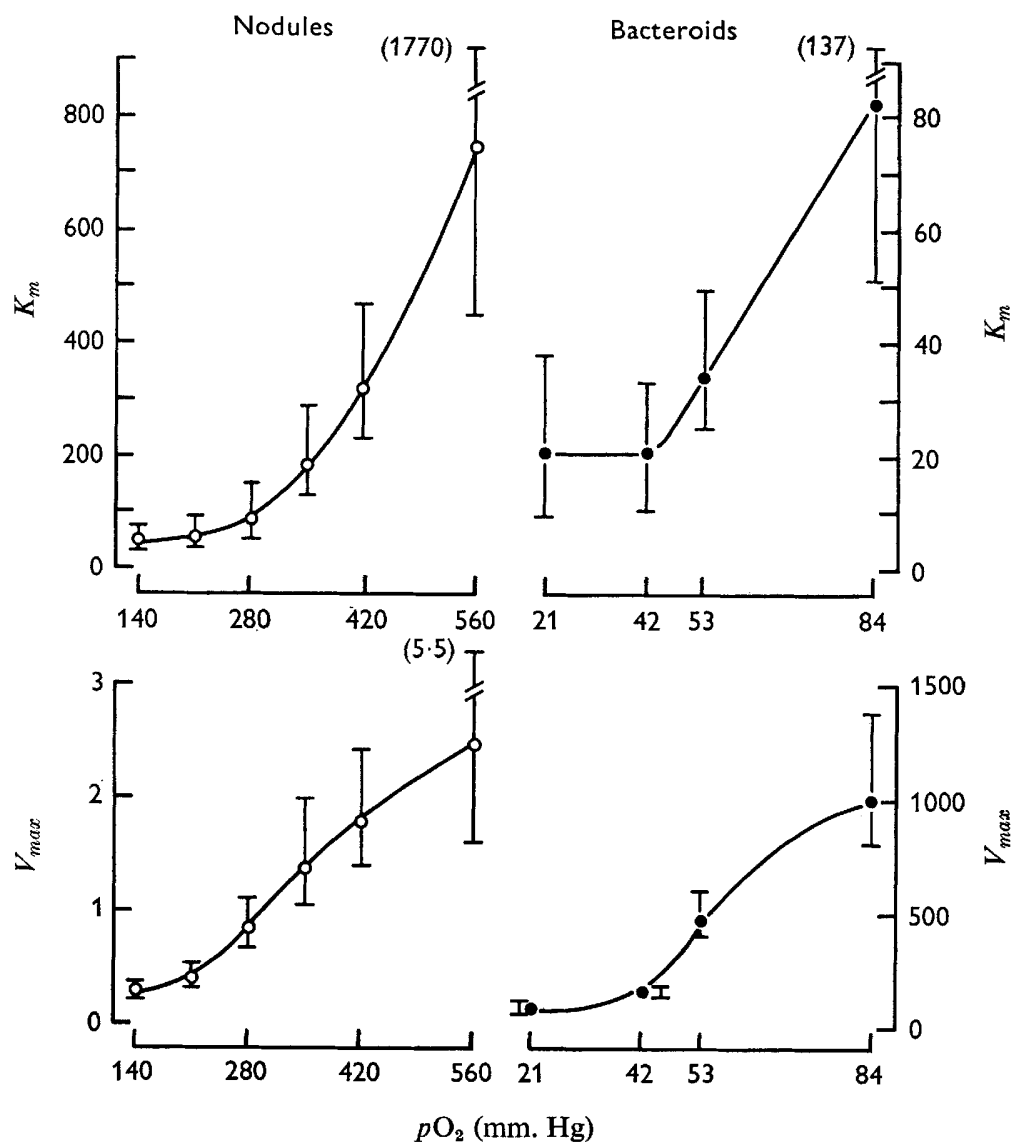

Fig. 4. Changes of $K_{m}$ and $V_{\max }$ as a function of $p \mathrm{O}_{2}$. Data for intact nodules from Bergersen (I962) $\mathrm{O}-\mathrm{O}$, and for bacteroid suspensions from the data of Fig. 30 . The values given are for $s$ measured in $\mathrm{mm}$. Hg: $v$ for nodules was atoms $\%$ excess $/ \mathrm{hr}$ and for bacteroids, $v$ was $\mathrm{m} \mu \mathrm{g}$. $\mathrm{N} / \mathrm{mg}$. protein $/ \mathrm{hr}$. The vertical lines give the magnitude of the $95 \%$ confidence limits.

$\mathrm{Hg}$, a $p \mathrm{O}_{2}$ of $140 \mathrm{~mm} . \mathrm{Hg}$, and $p \mathrm{~N}_{2}$ values of 56 to $140 \mathrm{~mm}$. Hg. Although inhibition by $\mathrm{CO}$ was greater at lower $p \mathrm{~N}_{2}$ values, suggesting that inhibition was competitive, it was not possible to apply kinetic treatment because of the slightly stimulatory effect of low pressures of $\mathrm{CO}$. Inhibition by $50 \%$ occurred in the $p \mathrm{CO}$ range of 4 to $8 \mathrm{~mm}$. $\mathrm{Hg}$ with a $p \mathrm{~N}_{2}$ range of 56 to $140 \mathrm{~mm}$. Hg. There was no effect of $\mathrm{CO}$ upon respiration or $\mathrm{H}_{2}$ evolution in these experiments. 


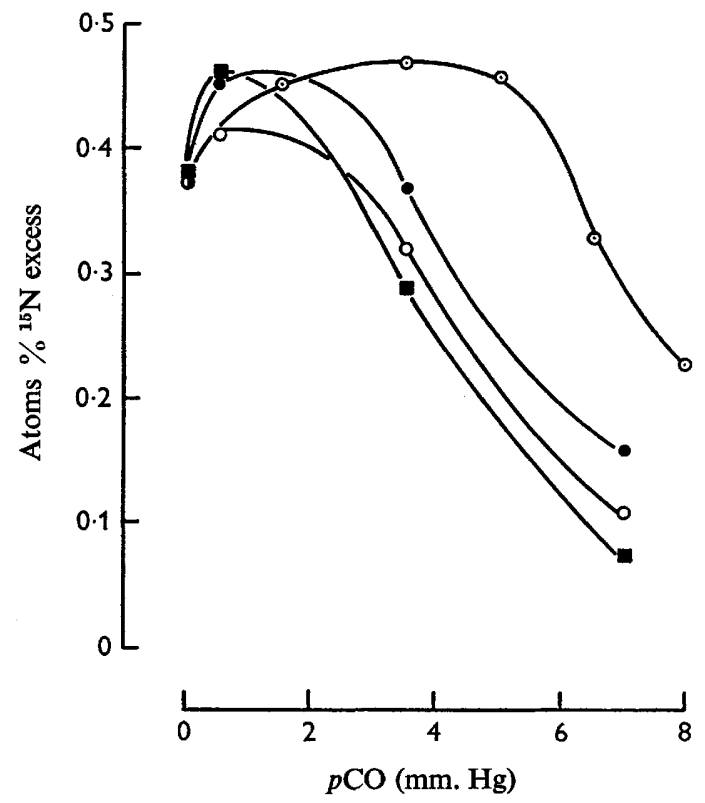

Fig. 5. Inhibition of nitrogen fixation in intact nodules by $\mathrm{CO}$. Fixation measured as atoms $\%{ }^{15} \mathrm{~N}$ in nodule non-protein-N. $p \mathrm{O}_{2} 140 \mathrm{~mm}$. $\mathrm{Hg} ; p \mathrm{~N}_{2}$ values $(\mathrm{mm} . \mathrm{Hg}$ ):

$\bigcirc-\bigcirc 99$, 97 and $\odot-\odot$ I $\odot$.
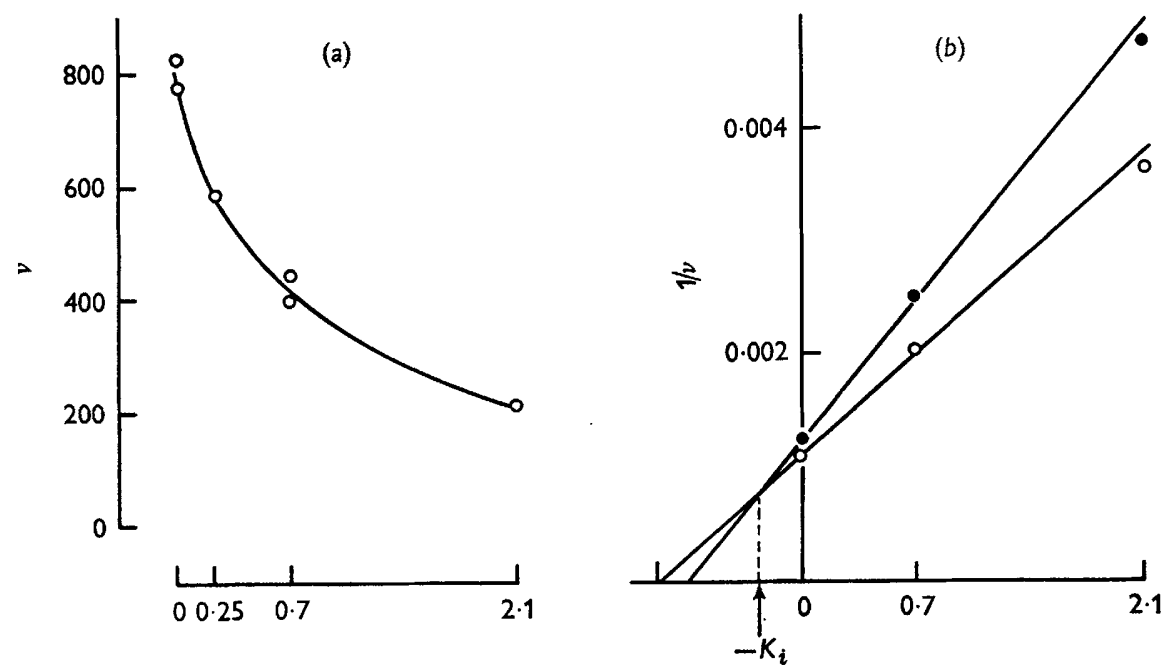

$p \mathrm{CO}(\mathrm{mm} . \mathrm{Hg})$

Fig. 6. Inhibition by $\mathrm{CO}$ of nitrogen fixation by $R$. japonicum bacteroid suspensions with a $p_{2} 42 \mathrm{~mm}$. Hg. $v=$ initial fixation rates in $\mathrm{m} \mu \mathrm{g}$. $\mathrm{N} / \mathrm{mg}$. protein $/ \mathrm{hr}$. (a) $p \mathrm{~N}_{2}=70 \mathrm{~mm}$. $\mathrm{Hg}$; data for two experiments. (b) Competitive inhibition shown by the method of Dixon (I953). $p \mathrm{~N}_{2}(\mathrm{~mm} . \mathrm{Hg})$ : 
The inhibition of nitrogen fixation by $\mathrm{CO}$ in thrice-washed bacteroid suspensions was studied in experiments at $\mathrm{pO}_{2} 42 \mathrm{~mm}$. Hg. The results are illustrated in Fig. 6, which shows that the inhibition was of standard form and that it was competitive (Dixon, 1953). The mean inhibitor constant $\left(K_{i}\right.$, the equilibrium constant of the reversible combination of the nitrogenase with $\mathrm{CO}$ ) was in these experiments $0.43 \pm 0 . \mathrm{I}$ with $s$ and $i$ measured in $\mathrm{mm} . \mathrm{Hg}$ pressure, and the mean $K_{m}$ was the same as that obtained in previous experiments with $\mathrm{pO}_{2} 42 \mathrm{~mm}$. Hg (Fig. 4). There was no effect of $\mathrm{CO}$ upon respiration by bacteroids at concentrations which produced almost complete inhibition of nitrogen fixation. At higher $\mathrm{CO}$ concentrations there was partial inhibition of $\mathrm{O}_{2}$-uptake which showed some evidence of light reversibility (Table 2).

\section{Table 2. Effects of $C O$ upon nitrogen fixation and respiration of bacteroid suspensions}

Suspensions incubated for $30 \mathrm{~min}$. at $25^{\circ}$. Gas phase contained $\mathrm{O}_{2}(35 \mathrm{~mm} . \mathrm{Hg})$ and ${ }^{15} \mathrm{~N}_{2}$ ( $140 \mathrm{~mm} . \mathrm{Hg}$ ). Nitrogen fixed measured as $\mathrm{NH}_{3}-\mathrm{N}$ after addition of carrier and respiration measured mass-spectrometrically as changes in partial pressure. One atm. $=700 \mathrm{~mm}$. $\mathrm{Hg}$. Results of two experiments. Darkened flasks wrapped in foil; lighted flasks illuminated by Phillips Altrilux lamp ( $500 \mathrm{~W})$ at a distance of I foot above the vessels.

\begin{tabular}{|c|c|c|c|}
\hline \multirow[b]{2}{*}{$p \mathrm{CO}(\mathrm{mm} . \mathrm{Hg})$} & \multirow[b]{2}{*}{$\mathrm{N}$ fixed $(\mu \mathrm{g})}$. & \multicolumn{2}{|c|}{ Respiration } \\
\hline & & $\Delta p \mathrm{O}_{2}$ (atm.) & $\Delta p \mathrm{CO}_{2}$ (atm.) \\
\hline $\begin{array}{l}0(\text { dark }) \\
0.06 \text { (dark) } \\
6.0 \text { (dark) }\end{array}$ & $\begin{array}{l}4 \cdot 71 \\
2 \cdot 88 \\
0 \cdot 18\end{array}$ & $\begin{array}{l}-81 \cdot 4 \times 10^{-4} \\
-80.7 \times 10^{-4} \\
-81 \cdot 8 \times 10^{-4}\end{array}$ & $\begin{array}{l}+73.2 \times 10^{-4} \\
+77.7 \times 10^{-4} \\
+77.8 \times 10^{-4}\end{array}$ \\
\hline o (light) & $4 \cdot 87$ & - III.9 $\times 10^{-4}$ & $+62.0 \times 10^{-4}$ \\
\hline I4 (dark) & 0 & $-69 \cdot 3 \times 10^{-4}$ & $+54.4 \times 10^{-4}$ \\
\hline I4 (light) & 0 & $-84.8 \times 10^{-4}$ & $+59.7 \times 10^{-4}$ \\
\hline 300 (dark) & 0 & $-69.0 \times 10^{-4}$ & $+57.3 \times 10^{-4}$ \\
\hline 300 (light) & 0 & $-92.0 \times 10^{-4}$ & $+54.3 \times 10^{-4}$ \\
\hline
\end{tabular}

\section{Experiments with cell-free extracts of bacteroids}

Bacteroids broken under argon fixed $\mathrm{N}_{2}$ into $\mathrm{NH}_{3}$ under strictly anaerobic conditions when supplied with dithionite and an ATP-generating system; unbroken bacteroids did not fix $\mathrm{N}_{2}$ under these conditions (Table 3). Omission of the dithionite from the broken-cell preparation decreased the activity by more than $90 \%$. In other experiments, omission of the creatine phosphate and creatine phosphokinase decreased nitrogen fixation by 30 to $60 \%$ and omission of ATP decreased it to zero.

In some experiments (e.g. Table 3), centrifugation in the chilled rotor of the Spinco, under argon, to remove coarse debris and intact bacteroids, resulted in considerable loss of activity. In a later experiment (Table 4) storage of the broken bacteroids in ice, under argon, resulted in loss of half the activity in $30 \mathrm{~min}$., as compared with the same preparation kept under argon at room temperature $\left(20^{\circ}\right)$. Centrifugation for $30 \mathrm{~min}$. at $100,000 \mathrm{~g}$ in an unchilled rotor with the chamber at $20-25^{\circ}$ and measurement of fixation by the pellet $\left(P_{100,000}\right)$ and the supernatant fluid $\left(S_{100,000}\right)$ showed that the highest specific activity resided in the latter fraction. This amount of fixation corresponded to $70 \%$ of the activity of the unfractionated broken bacteroids, kept under argon at $20^{\circ}$ for the same time (Table 4 ).

The time course of fixation was linear for the first $30 \mathrm{~min}$. (Fig. 7a), and these initial rates were used for the calculation of $K_{m}$ in experiments in which a range of $\mathrm{N}_{2}$ 
pressures was used (Fig. $7 b$ ). Values of $K_{m}$ with any one extract could be obtained within quite narrow confidence limits (Fig. $7 b$ ). However, there was considerable fluctuation between values obtained with extracts prepared on different days, even when rigidly standardized methods were used. In four experiments $K_{m}$ was measured

\section{Table 3. Nitrogen fixation by cell-free extracts of bacteroids}

Vessels contained the preparations as listed in a total volume of $3.0 \mathrm{ml}$. Succinate, $100 \mu \mathrm{moles} / \mathrm{vessel}$. ATP-generating (ATP-gen.) system: ATP (Na salt) $6 \mu$ moles; creatine phosphate $150 \mu$ moles; creatinecreatine-phosphokinase $2 \mathrm{mg}$./vessel, $\mathrm{Na}_{2} \mathrm{~S}_{2} \mathrm{O}_{4}, 24 \mu \mathrm{moles} / \mathrm{vessel}$. One atmosphere $(700 \mathrm{~mm}$. $\mathrm{Hg}$ ) was made up of the gases shown and the balance with argon. Preparations were incubated for $\mathrm{I} \mathrm{hr}$ at $25^{\circ}$ with shaking.

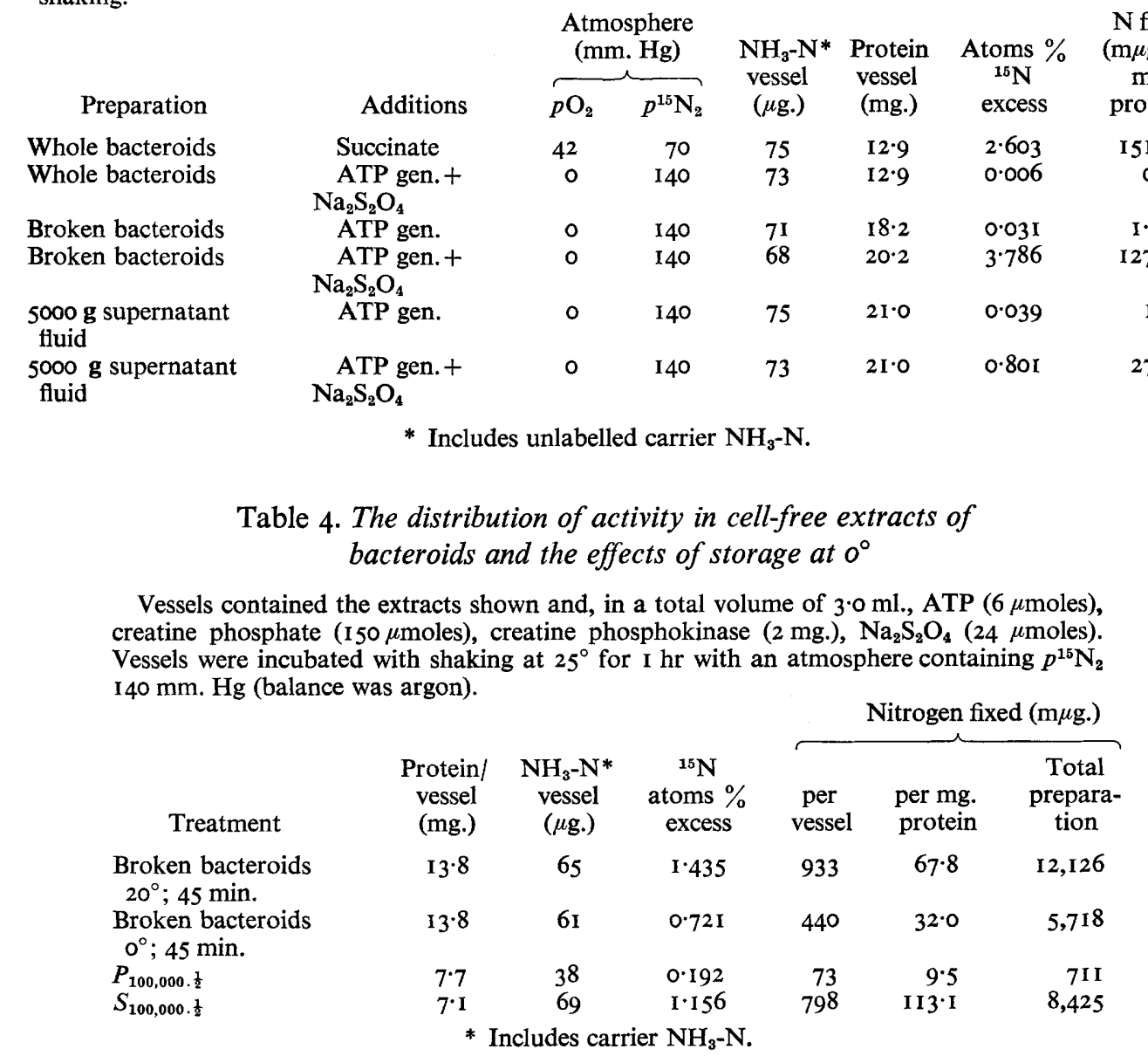

as $6 \mathrm{I} \cdot 7,64 \cdot 5,95 \cdot 0$ and $\mathrm{I} \mathrm{I} 8 \cdot 0\left(\mathrm{~N}_{2}\right.$ pressure in $\mathrm{mm}$. $\left.\mathrm{Hg}\right) . V_{m a x}$ varied from I to $2 \mathrm{~m} \mu$ moles $\mathrm{NH}_{3} /$ min. mg. protein, higher values being obtained with experiments in which $K_{m}$ values were low. The variation was too great to permit pooling of data to obtain confidence limits, as was done for bacteroid suspensions. These results show a three- to five-fold increase in $K_{m}$ for extracts, as compared with the value for intact bacteriods measured in the range of $p \mathrm{O}_{2}$ in which $K_{m}$ was unaffected.

The effects of $\mathrm{CO}$ were measured in a manner similar to measurements made with 


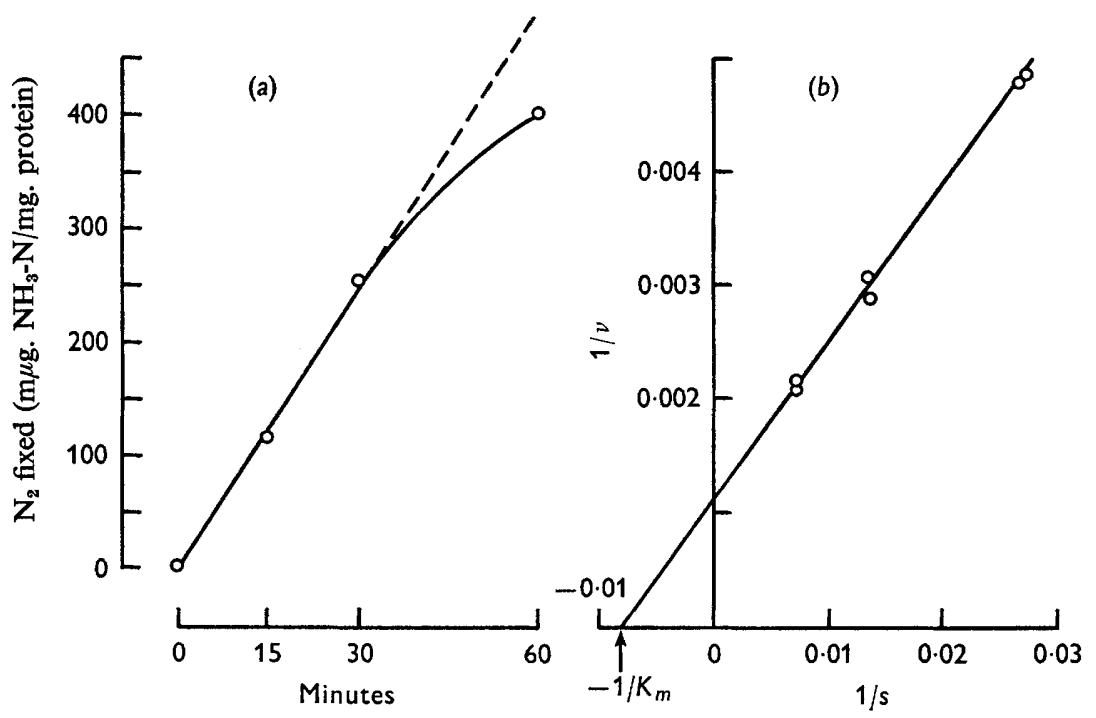

Fig. 7. (a) Nitrogen fixation by a cell-free extract of bacteroids of $R$. japonicum. Vessels contained II. $4 \mathrm{mg}$. $S_{100,000 . \frac{1}{2}}$ protein, ATP (6 $\mu$ moles), creatine phosphate (I50 $\mu$ moles), creatine phosphokinase $\left(0.8 \mathrm{mg}\right.$.), $\mathrm{Na}_{2} \mathrm{~S}_{2} \mathrm{O}_{4}(24 \mu$ moles), in a total volume of $4 \mathrm{ml}$. Incubated with ${ }^{15} \mathrm{~N}_{2}$ (119 mm. Hg) with shaking at $25^{\circ}$. (b) Determination of $K_{m}$ for nitrogen fixation by $S_{100,000 . \frac{1}{2}}$ protein. Details as in $(a) . s$ measured in $\mathrm{mm}$. $\mathrm{Hg}$ and $v$ measured as the initial velocity (o to $30 \mathrm{~min}$.) in $\mathrm{m} \mu \mathrm{g}$. $\mathrm{N} / \mathrm{mg}$. protein $/ \mathrm{hr}$. Data for one experiment.
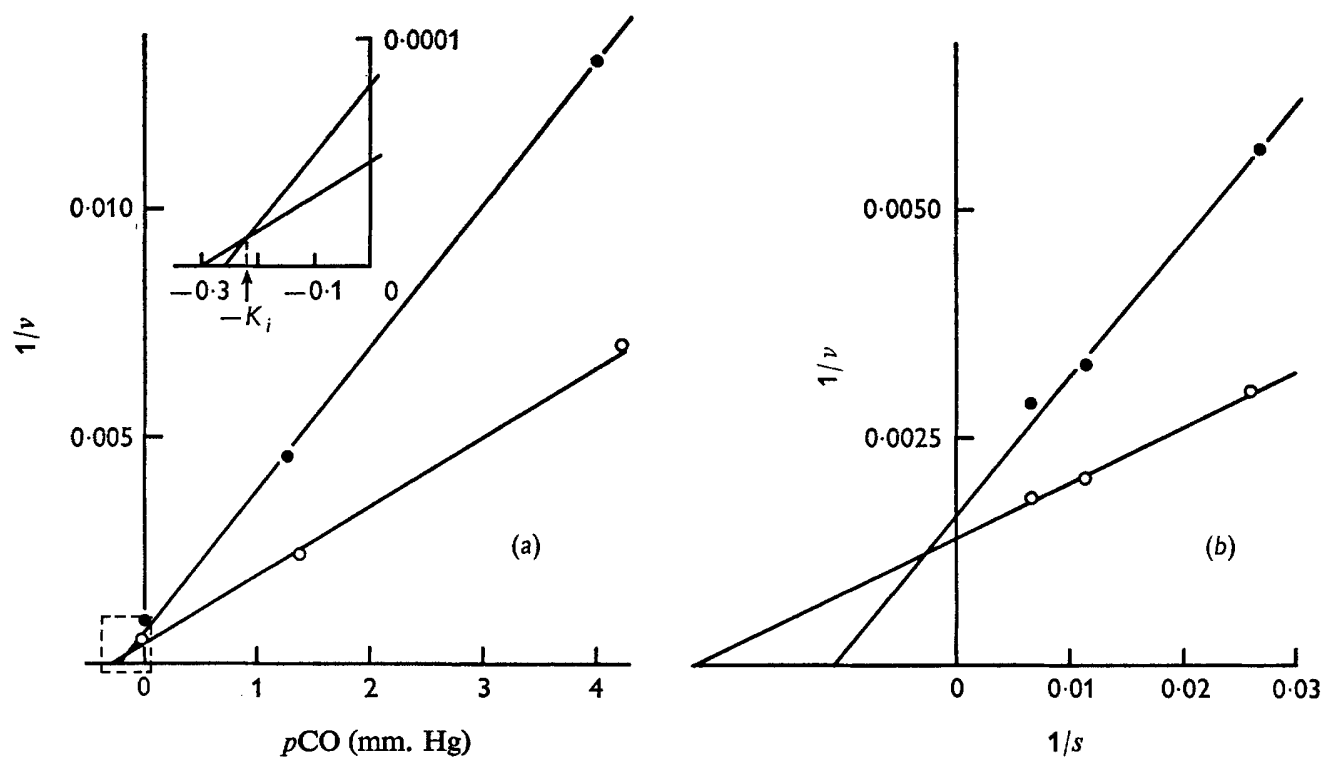

Fig. 8. Inhibition by $\mathrm{CO}$ of nitrogen fixation by cell-free extracts of bacteroids of $R$. japonicum. (a) Determination of $K_{i}$; data for one experiment. $p \mathrm{~N}_{2}(\mathrm{~mm} . \mathrm{Hg}): 0-\mathrm{O}, \mathrm{I} 40$ and 35. (b) Plot of data confirming competitive inhibition. $i$ and $s$ measured in $\mathrm{mg}$. $\mathrm{Hg}$ pressure. $v$ measured in $\mathrm{m} \mu \mathrm{g}$. $\mathrm{N} / \mathrm{mg}$. protein $/ \mathrm{hr}$. Other details as described in the text. $p \mathrm{CO}$ $(\mathrm{mm} . \mathrm{Hg}): \mathrm{O}-\mathrm{O} O$ and $-\mathrm{I} \cdot 3$. The intercepts at $\mathrm{I} / \mathrm{s}=\mathrm{O}$ are not significantly different. 
intact bacteroids. Carbon monoxide was a competitive inhibitor of nitrogen fixation in cell-free extracts with a $K_{i}$ of $0.23 \pm 0.02(\mathrm{~mm}$. $\mathrm{Hg})$, but the lines for the two substrate concentrations intercepted at a low value of $\mathrm{r} / v$ (Fig. $8 a$ ). A double reciprocal plot (Dixon, I953) was therefore used to confirm the competitive nature of the inhibition (Fig. 8b). In all of these experiments, $K_{m}$ varied between 62 and $77 \mathrm{~mm}$. $\mathrm{Hg}$.

\section{DISCUSSION}

The main findings of this work are summarized in Table 5 in which the effects of $\mathrm{O}_{2}$ and $\mathrm{CO}$ upon the kinetics and other properties of the nitrogen-fixing system are compared for nodules, bacteroid suspensions and cell-free extracts of bacteroids. The results, which showed that the activity of cell-free extracts was decreased when stored at $0^{\circ}$, were similar to observations made with extracts of Clostridium pasteurianum and Azotobacter vinelandii (Dua \& Burris 1965; R. C. Burns, personal communication). We have found no evidence of this effect before the disruption of the bacteroids.

Table 5. Comparison of nitrogen fixation by intact nodules, bacteroid suspensions and cell-free extracts of bacteroids as influenced by oxygen and carbon monoxide

\begin{tabular}{|c|c|c|c|}
\hline & Intact nodules & Bacteroid suspensions & Extracts \\
\hline Effects of $\mathrm{O}_{2}$ & $\begin{array}{l}\text { Required; fixation linear } \\
\text { with time at all } p \mathrm{O}_{2} \\
\text { values. No fixation below } \\
p \mathrm{O}_{2} 3.5 \mathrm{~mm} . \mathrm{Hg} \text {; maxi- } \\
\text { mum at } 300 \text { to } 350 \mathrm{~mm} \text {. } \\
\mathrm{Hg} \text {; inhibited at higher } \\
p \mathrm{O}_{2} \text { values }\end{array}$ & $\begin{array}{l}\text { Required; fixation linear } \\
\text { with time below } \mathrm{pO}_{2} \\
\mathrm{I} 4 \mathrm{~mm} \text {. } \mathrm{Hg} \text {; higher values } \\
\text { increase initial rates up } \\
\text { to } 85 \mathrm{~mm} . \mathrm{Hg} \text { but the } \\
\text { time course is shortened, } \\
\text { due to inactivation }\end{array}$ & $\begin{array}{l}\text { Causes inactivation; } \\
\text { requirement replaced } \\
\text { by use of ATP } \\
\text { generating system + } \\
\mathrm{Na}_{2} \mathrm{~S}_{2} \mathrm{O}_{4}\end{array}$ \\
\hline$K_{m}\left(\mathrm{~N}_{2}\right)(\mathrm{mm} . \mathrm{Hg})$ & $\begin{array}{l}50 \cdot 3\left\{\begin{array}{c}37 \cdot 0^{*} \\
7 \cdot 8\end{array}\right\} \text { in air } \\
\text { increases at } p \mathrm{O}_{2} \text { above } \\
300 \mathrm{~mm} . \mathrm{Hg}\end{array}$ & $\begin{array}{l}20.4\left\{\begin{array}{l}10 \cdot 7^{*} \\
33.4\end{array}\right\} \text { at low } p \mathrm{O}_{2} \\
\text { increases at } p \mathrm{O}_{2} \text { above } \\
42 \mathrm{~mm} . \mathrm{Hg}\end{array}$ & $\begin{array}{l}\text { Variable; } 6 \mathrm{I} \text { to I I } 8 \\
\text { (compare } 42 \cdot 5 \text { ob- } \\
\text { tained by Koch et al. } \\
1967 b \text { ) }\end{array}$ \\
\hline Effects of $\mathrm{CO}$ & $\begin{array}{l}\text { Inhibitory; } 50 \% \text { inhibited } \\
\text { at } p \mathrm{CO} 4 \text { to } 8 \mathrm{~mm} . \mathrm{Hg} \text {. } \\
\text { Less inhibition at higher } \\
p \mathrm{~N}_{2} \text { but data not } \\
\text { suitable for kinetic } \\
\text { analysis }\end{array}$ & $\begin{array}{l}\text { Competitive inhibition: } \\
K_{\mathrm{i}}=0.43 \pm 0 . \mathrm{I} \uparrow \dagger \mathrm{mm} . \mathrm{Hg}\end{array}$ & $\begin{array}{l}\text { Competitive inhibition: } \\
K_{\mathrm{i}}=0.23 \pm 0.02 \dagger \mathrm{mm} \text {. } \\
\mathrm{Hg}\end{array}$ \\
\hline
\end{tabular}

The effects of oxygen upon nitrogen fixation by bacteroids in suspension or in host tissue can be summarized as follows. (I) Oxygen is required, for nitrogen fixation by nodules and bacteroid suspensions, to provide available energy, as shown by the increases in $v$ and $V_{\text {max }}$ when the $\mathrm{pO}_{2}$ value was increased. (2) The nitrogen-fixing system is inactivated by free oxygen. This is seen from the shortened time-course of fixation by isolated bacteroids with increasing $p \mathrm{O}_{2}$ values and by deliberate aeration during preparation. (3) The apparent affinity of nitrogenase for $\mathrm{N}_{2}$ is decreased in the presence of oxygen, as shown by the increased $K_{m}$ with increasing $p \mathrm{O}_{2}$. (4) The effects 2 and 3 must be separate, because the time-course of fixation by intact nodules is not shortened at high $p \mathrm{O}_{2}$ values where $K_{m}$ is sharply increased (Bergersen, 1962). This implies that the bacteroids are protected in the intact tissue from the inactivating effects of 
high $\mathrm{pO}_{2}$ but are exposed to its kinetic effects (see discussion in Bergersen \& Turner 1967). (5) $\mathrm{O}_{2}$ and $\mathrm{N}_{2}$ may be regarded as being in competition for reducing power. This competition may not occur at the $\mathrm{N}_{2}$-binding site but may be an expression of the presence of two divergent electron-transport pathways, one of which terminates with $\mathrm{O}_{2}$ and the other with $\mathrm{N}_{2}$. The increase in $\mathrm{O}_{2}$-uptake which accompanied cessation of fixation by bacteroids (Fig. 2), and the kinetic experiments with bacteroids in which it was found that $\mathrm{O}_{2}$-uptake was greatest at the lowest $\mathrm{N}_{2}$ pressures, illustrate this. Because of the rapid inactivation of bacteroids at high $\mathrm{pO}_{2}$ values it was not possible to reach concentrations of $\mathrm{O}_{2}$ equivalent to those which produced inhibition in intact nodules. The nature of the apparent competition, therfore, remains in doubt because the cell-free system with dithionite is incompatible with the use of oxygen as an inhibitor.

Lind \& Wilson (194I) showed that carbon monoxide was a specific but non-competitive inhibitor of nitrogen fixation by growing nodulated redclover plants. Except for some studies on the effects of CO upon the leghaemoglobin of nodules (Smith, 1949) and upon hydrogen metabolism (Hoch, Schneider \& Burris, 1960; Bergersen, 1963), little work has been done with the legume system. Inhibition of nitrogen fixation by $\mathrm{CO}$ has been shown to be competititive with $\mathrm{N}_{2}$ in cell-free extracts of Clostridium pasteurianum, with a $K_{i}$ of about $0.3 \mathrm{~mm}$. $\mathrm{Hg}$ (Lockshin \& Burris, 1965). The form of the data for intact nodules shows why the competitive nature of inhibition of nitrogen fixation by $\mathrm{CO}$ was not shown earlier. The slightly stimulatory effect of low concentrations ( 2 to $6 \mathrm{~mm}$. $\mathrm{Hg}$ ) confounds kinetic treatment of the data. No explanation of this effect is offered; it may be related to binding of $\mathrm{CO}$ by the leghaemoglobin of the intact tissue. These effects were avoided when well-washed bacteroids were used and it was clearly shown that $\mathrm{CO}$ was a competitive inhibitor. The $K_{i}$ value obtained $(0.43 \pm 0.1 \mathrm{I})$ is very near to the value obtained by Lockshin \& Burris (1965) with C. pasteurianum extracts; the value obtained with cell-free Rhizobium bacteroid extracts was slightly lower. When the solubilities in water at $25^{\circ}$ of $\mathrm{CO}$ and $\mathrm{N}_{2}$ are compared at the pressures corresponding to the $K_{i}$ and $K_{m}$ values for bacteroids (at $p \mathrm{O}_{2} 42 \mathrm{~mm}$. $\mathrm{Hg}$ ), concentrations of $0.54 \mu \mathrm{M}$ for $\mathrm{CO}$ and $16.8 \mu \mathrm{M}$ for $\mathrm{N}_{2}$ are obtained. That is, the nitrogenase of intact bacteroids has about 30 times the apparent affinity for $\mathrm{CO}$ that it has for $\mathrm{N}_{2}$.

Studies with intact growing Azotobacter vinelandii (Wilson, Burris \& Lind, 1942) and Clostridium pasteurianum (Westlake \& Wilson, 1959) have indicated a $K_{m}$ for nitrogen fixation of $\mathrm{I} 5$ to $23 \mathrm{~mm}$. $\mathrm{Hg}(0.02$ to 0.03 atmosphere). These values are comparable with the value of 20 (Fig. 4) obtained for non-growing Rhizobium bacteroids in the range of $p \mathrm{O}_{2}$ in which $K_{m}$ was not affected. The higher value for $K_{m}$ of 50 to 60 , obtained at the lower $p \mathrm{O}_{2}$ values with intact nodules, is presumed to arise as a consequence of a $\mathrm{N}_{2}$ concentration gradient extending from the external atmosphere to the bacteroids within the host tissue.

After the work reported here was completed Koch et al. $(1967 b)$ reported a $K_{m}$ of 0.056 atmosphere $(42.6 \mathrm{~mm}$. Hg) for nitrogen fixation by cell-free extracts of Rhizobium bacteroids. This value is less than that obtained by us, but it is substantially higher than the $K_{m}$ for nitrogen fixation by intact bacteroids. The reported $K_{m}$ values for cell-free extracts of Clostridium and Azotobacter are 4 to Io times higher than values for intact nitrogen-fixing bacteria and in general have been found to be 0.16 to 0.20 atmosphere, i.e. I22-I52 mm. Hg (e.g. Mortenson, 1964). Dilworth, 
Subramanian, Munson \& Burris (1965) showed that this increase in $K_{m}$ might be due in part to the effects of $\mathrm{H}_{2}$ when substantial evolution of $\mathrm{H}_{2}$ occurs or when fixation is measured in the presence of $\mathrm{H}_{2}$ and acetylphosphate. $\mathrm{H}_{2}$ is a competitive inhibitor of nitrogen fixation and therefore tends to increase the apparent $K_{m}$. In the work with cell-free extracts of Rhizobium bacteroids described here, $\mathrm{H}_{\mathbf{2}}$ was always present in the gas phase but only to the extent of 0.1 to $0.2 \mathrm{~mm}$. Hg., concentrations too small to affect $K_{m}$.

The nitrogen-fixation reaction may be expressed as follows:

$$
E+\mathrm{N}_{2} \underset{k_{2}}{\stackrel{k_{1}}{\rightleftarrows}} E: \mathrm{N}_{2} \underset{k_{3}}{\stackrel{+6 \mathrm{H}}{\longrightarrow}} E+2 \mathrm{NH}_{3},
$$

where $E$ is the nitrogenase complex and $k_{1}, k_{2}$ and $k_{3}$ are the respective rate constants. Strictly, $K_{m}=k_{2} / k_{1}$, but in the method used to measure $K_{m}$, the relationship between $\mathrm{N}_{2}$ concentration and rate of $\mathrm{NH}_{3}$ production is measured and it is assumed that $k_{3}$ is not rate-limiting. The following considerations suggest that $k_{3}$ cannot be ignored, especially when using cell-free extracts. Carbon monoxide is not reduced by nitrogenase to any significant extent; we have been unsuccessful in a search for any of the likely products of such a reaction. Therefore, in measuring $K_{i}(\mathrm{CO})$, we have been dealing only with the affinity of the binding-site. This is also the site at which $\mathrm{N}_{2}$ is bound, because $\mathrm{CO}$ is a competitive inhibitor of nitrogen fixation; it is also of the same mass and is iso-electronic with $\mathrm{N}_{2}$. We have shown that the binding of $\mathrm{CO}$ to nitrogenase is relatively unaffected by disruption of the Rhizobium bacteroids because the $K_{i}(\mathrm{CO})$ was 0.4 for bacteroids and 0.2 for extracts. It is therefore unlikely that the binding-site of the enzyme was affected by disruption of the bacteroids. It is thus possible that the apparent three- to five-fold increase in $K_{m}\left(\mathrm{~N}_{2}\right)$ which occurs when the bacteroids are disrupted is due to a decrease in $k_{3}$. That is, the substitution of dithionite and ATP for the natural reducing system leads to less rapid production of $\mathrm{NH}_{3}$.

The authors express their appreciation to Mr G. A. McIntyre for the statistical treatment of the kinetic data and to Mrs A. Marcina and Mrs L. Hush for their part in the technical aspects of the experimental programme.

\section{REFERENCES}

APrison, M. H., MAGEe, W. E. \& BurRis, R. H. (I954). Nitrogen fixation by excised soybean nodules. J. biol. Chem. 208, 29.

BERGERSEN, F. J. (1958). The bacterial component of soybean root nodules; changes in respiratory activity, cell dry weight and nucleic acid content with increasing nodule age. J. gen. Microbiol. I9, 3 I2.

BERGERSEN, F. J. (1962). The effects of partial pressure of oxygen upon respiration and nitrogen fixation by soybean root nodules. J. gen. Microbiol. 29, I I 3 .

BERGERSEN, F. J. (1963). The relationship between hydrogen evolution, hydrogen exchange, nitrogen fixation and applied oxygen tension in soybean root nodules. Aust. J. Biol. Sci. 16, 669.

BERGERSEN, F. J. (1966). Some properties of nitrogen-fixing breis prepared from soybean root nodules. Biochim. biophys. Acta 130, 304.

Bergersen, F. J. \& TuRNer, G. L. (1967). Nitrogen fixation by the bacteroid fraction of breis of soybean root nodules. Biochim. biophys. Acta r4I, 507. 
Bulen, W. A., Burns, R. C. \& LeComte, J. R. (1965). Nitrogen fixation; hydrosulphite as electron donor with cell-free preparations of Azotobacter vinelandii and Rhodospirillum rubrum. Proc. natn. Acad. Sci., U.S.A. 53, 532.

Burns, R. C. \& BULEN, W. A. (I965). ATP dependent hydrogen evolution by cell-free preparations of Azotobacter vinelandii. Biochim. biophys. Acta ro5, 437.

Dilworth, M. J., Subramanian, D., Munson, T. O. \& Burris, R. H. (1965). The adenosine triphosphate requirement for nitrogen fixation in cell-free extracts of Clostridium pasteurianum. Biochim. biophys. Acta 99, 486.

Dixon, M. (1953). The determination of enzyme inhibitor constants. Biochem. J. 55, 170.

DUA, R. D. \& BURRIs, R. H. (1965). Studies of cold lability and purification of a nitrogen-activating enzyme. Biochim. biophys. Acta 99, 504.

FraENKel-CONRAT, H. (1957). Methods for investigating the essential groups for enzyme activity. Meth. Enzymol. 4, 247.

FRENEY, J. R. \& WetSElAAR, R. (1967). The determination of mineral nitrogen in soil with special reference to nitrate. CSIRO Australia, Div. Plant Ind. Tech. Paper, 23.

Hoch, G., SchneIder, K. C. \& Burris, R. H. (1960). Hydrogen evolution and exchange and conversion of $\mathrm{N}_{2} \mathrm{O}$ to $\mathrm{N}_{2}$ by soybean root nodules. Biochim. biophys. Acta 37, 273.

Koch, B., Evans, H. J. \& Russell, S. (1967a). Reduction of acetylene and nitrogen by breis and cell-free extracts of soybean root nodules. Plant Physiol. 42, 466.

Koch, B., Evans, H. J. \& Russell, S. $(1967 b)$. Properties of the nitrogenase system in cell-free extracts of bacteroids from soybean root nodules. Proc. natn. Acad. Sci., U.S.A. 58, 1343.

LIND, C. J. \& WILSON, P. W. (I94I). Mechanism of biological nitrogen fixation. VIII. Carbonmonoxide as an inhibitor for nitrogen fixation by red clover. J. Am. chem. Soc. 63, 351 I.

LOCKSHIN, A. \& BURRIS, R. H. (1965). Inhibitors of nitrogen fixation in extracts from Clostridium pasteurianum. Biochim. biophys. Acta III, I.

MORTENSON, L. E. (I964). Ferredoxin and ATP requirements for nitrogen fixation in cell-free extracts of Clostridium pasteurianum. Proc. natn. Acad. Sci., U.S.A. 52, 272.

Mortenson, L. E. (1966). Components of cell-free extracts of Clostridium pasteurianum required for ATP-dependent $\mathrm{H}_{2}$ evolution from dithionite and for nitrogen fixation. Biochim. biophys. Acta $127,18$.

SмmTH, J. D. (1949). Haemoglobin and the oxygen uptake of leguminous root nodules. Biochem. $J$. 44, $59 \mathrm{I}$.

Westlake, D. W. S. \& Wilson, P. W. (1959). Molecular hydrogen and nitrogen fixation by Clostridium pasteurianum. Can. J. Microbiol. 5, 617.

Wilson, P. W., Burris, R. H. \& LIND, C. J. (1942). The dissociation constant in nitrogen fixation by Azotobacter. Proc. natn. Acad. Sci., U.S.A. 28, 243. 